УДК 330.341 .1

JEL: D 20; L 50; O 31.

DOI: http://doi.org/10.32750/2019-0101

\author{
Бойко Олена Миколаївна \\ кандидат економічних наук, старший науковий співробітник, \\ провідний науковий співробітник Державна установа \\ «Інститут економіки та прогнозування НАН України» \\ ORCID ID 0000-0002-6567-1679 \\ e-mail:bhelena@ukr.net
}

\title{
ДОСВІД УКРАЇНИ ТА КИТАЮ ЩОДО СТВОРЕННЯ ОРГАНІЗАЦІЙНИХ ФОРМ ІННОВАЦІЙНОЇ ДІЯЛЬНОСТІ
}

\begin{abstract}
Анотація. В статті розглянуто ініціативу розвитку індустріальних парків, зокрема в напрямку трансрегіонального співробітниитва між КНР та Сінгапуром (індустріальний парк «м. Сучжоу Сінгапур", а також KHP та Білорусією (індустріальний парк "GreatStone"). здійснено моніторинг розвитку індустріальних парків на території Китаю (індустріальний парк «Lianyungang Xinpu», індустріальний парк в Ханчжоу) та України (КП «Індустріальний парк «Рогань», «Індустріальний парк «Свєма», а також індустріальні парки "Industrial Forpost", «Славута», «Чексіл»). Визначено тенденції функціонування індустріальних парків, а також спільні та відмінні риси їх розвитку в КНР та в Україні.

Перспективним напрямком $\epsilon$ створення українсько-китайських індустріальних парків, тому проаналізовано особливості їх створення та функціонування, пріоритетні напрямки та ризики. Визначено особливості кластерних ініціатив, які розглянуто на прикладі України та КНР в аспекті галузевого розвитку. Розглянуто моделі формування державної кластерної політики. Проаналізовано особливості функціонування високотехнологічної і низькотехнологічної кластерної політики.

В теоретико-методологічному аспекті розглянуто типологію діючих кластерів здійснено моніторинг функиіонування кластерів на території України та КНР. Визначено пріоритетні напрямки їхнього подальшого розвитку та ризики.

Розглянуто досвід розробки спеціальних програм функиіонування кластерів в КНР та Україні. Окрему увагу приділено питанню кооперачії між Торгово-промисловою палатою (ТПП) і кластерами в КНР та в Україні.

Визначено інституційно-правові засади функціонування організаційних форм інноваційної діяльності реального сектору економіки України та КНР, зокрема на прикладі індустріальних парків (у тому числі законодавчий пакет №№ 2554 a-д та 2555 а-д), а також кластерів. Розроблено пропозиції щодо особливостей подальшого їх створення, розвитку.
\end{abstract}

Ключові слова: індустріальний парк; кластер; кластерна ініціатива; транс регіональне співробітництво; індустріально-правове забезпечення.

(c) О. М. Бойко, 2019

\section{ВСТУП}

Стратегічними партнерами (понад 25 років) є Україна та КНР, що відкриває можливості для поглиблення співробітництва та реалізації спільних проектів у соціально-економічному розвитку, зокрема в напрямку вдосконалення промислової політики. Це є вагомим інструмен- том зняття штучних регуляторних перешкод на шляху розвитку бізнесу двох країн, створення сприятливих умов для залучення інвестицій з КНР в економіку України через удосконалення нормативно-правового забезпечення, залучення капіталу у модернізацію вітчизняного виробництва, у тому числі шляхом створення 
та розвитку спеціальних форм організації інноваційної діяльності (кластери, індустріальні (промислові) парки та ін.).

Постановка проблеми полягає у визначенні основних засад розвитку основних форм інноваційної діяльності в контексті українсько-китайського співробітництва; дослідженні основних тенденцій основних форм інноваційної діяльності в Україні та КНР в останні роки, а також розробці пропозиції щодо вдосконалення законодавчих та інших нормативно-правових актів з питань діяльності індустріальних парків, кластерів.

Аналіз останніх досліджень і публікацій. Особливості інноваційної діяльності на основі функціонування організаційних форм інноваційної діяльності промислового сектору економіки країни, у тому числі за рахунок розвитку наукових та індустріальних парків, кластерів висвітлювали у своїх наукових працях такі видатні фахівці, як Андріанов В., Андрусов У., Асаул А., Баронов В., Бовін А., Бойко О., Брушко Ю., Гальчинський Н., Гончаров А., Дмитрієв Д., Евтушин В., Егоров I., Загвойська Л., Зубаревич Н., Іванов С., Костюнін Г., Ляшенко В., Молдован О., Новіков А., Приходько С., Рудий К., Санатов Д., Селіванов А., Соколенко С., Якимович В. та ін.

Мета статті. Метою дослідження $€$ визначення особливостей створення та розвитку індустріальних парків і кластерів як основних інструментів інноваційного співробітництва у реальному секторі економіки між Україною та КНP.

\section{РЕЗУЛЬТАТИ ДОСЛІДЖЕННЯ}

Одним із ефективних способів підвищення діяльності промислових підприємств є створення нових форм організації інноваційної діяльності, вагоме значення серед яких набувають індустріальні парки.

Сьогодні за даними UNIDO у світі функціонує понад 20 тис. індустріальних парків (Китай - 54, Україна - 49 од.) [1]. В КНР індустріальні парки прийнято називати індустріальними зонами, які формують близько 10,0\% ВВП, акумулюють 30,0 \% прямих іноземних інвестицій та генерують 37,0 \% товарного експорту країни. В них працює близько 4 млн. осіб. Найбільш відомими є такі індустріальні парки, як [2-5]:

- китайський індустріальний парк «Lianyungang Xinpu» (провінція Цзянсу) займає площу 4800 га, а загальна площа об'єктів нерухомості - 200 млн м². Спеціалізація виробничої діяльності індустріального парку текстильне виробництво, авіабудування, суд- нобудування, торговельно-збутова діяльність, проведення наукових досліджень та впровадження розробок тощо. Обсяг залучення інвестицій - 4 млрд юанів;

- китайський індустріальний парк в Ханчжоу створено в 1993 р. Він займає площу 5000 га. Діяльність індустріального парку пов'язана з залученням 180 компаній, в т.ч. зарубіжних (“IBM", "LG”, "Pepsi”, "Merck Sharp \& Dohme”, "Panasonic" тощо.). Сумарна виручка становить понад 5 млрд. дол. США в рік. Стратегія розвитку індустріального парку пов'язана з розвитком таких видів економічної діяльності в регіоні, як електроніка, виробництво продуктів харчування, машинобудування, біомедицина;

- Китайсько-сінгапурський індустріальний парк «м. Сучжоу - Сінгапур», площею 260 км², на якій розташовано 330 компаній (79 найбільших корпорацій світу 3 списку Fortune-500) 3 чисельністю працюючих 35 тис. осіб. Обсяг залучених інвестицій - 100 млрд дол. США. Особливістю функціонування індустріального парку є те, що це об’єкт спільного освоєння КНР та Сінгапуру (частки розподілені наступним чином: 52,0 \% акцій належить консорціуму китайських компаній, 28 \% - сінгапурському консорціуму, $10 \%$ - компанії "The Hong Kong and China Gas Co., Ltd., 5 \% компанії "Singapore CPG Corporation Pte., Ltd., 5,0 \% - компаніi "Suzhou New District High-tech Industrial Stock Co., Ltd.”). Статутний капітал індустріального парку спочатку становив 50 млн. дол. США, згодом збільшився до 100 млн. дол. США (1995 р.), досягнувши 125 млн. дол. США (2005 р.). 3 метою успішного розвитку об'єкта було створено трипланові управлінські та робочі органи, які являють собою спільну раду урядів Китаю та Сінгапуру, двосторонній комітет, конкретні установи по зв'язку тощо. Діє особлива система планування розвитку міста, яка передбачає розроблення детального плану, який здатен поєднувати китайську специфіку з сінгапурським досвідом у сфері міського планування і будівництва, економічного розвитку, суспільного адміністративного управління тощо. Організовано шість державних технічних платформ для місцевих біомедичних компаній, які здійснюють діяльність у сфері надання послуг щодо аналізу наркотиків, випробування нових лікарських препаратів, технологій скринінгу лікарських засобів тощо;

- Китайсько-білоруський індустріальний “GreatStone”, загальною площею 112,5 км². Проект розвивається в рамках міждержавного китайсько-білоруського співробітництва та підписаних відповідних міжурядових документів. В якості резидентів індустріального парку мо- 
жуть виступати будь-які компанії незалежно від країни походження капіталу. Для резидентів індустріального парку створено сприятливий інвестиційний клімат, гарантований як національним законодавством, так і спеціальними міжнародними угодами і зобов'язаннями. Зокрема, це такі преференції, як: пільгове оподаткування за формулою «10+10» (звільнення від всіх корпоративних податків на 10 років з моменту реєстрації в якості резидента парку і зниження діючих ставок податків на 50,0 \% в наступні 10 років діяльності в парку); режим вільної митної зони, що дає право без сплати митних платежів (мита, ПДВ, акцизів) ввезення товарів (сировини, матеріалів) за умови їх подальшої переробки та експорті за межі країн Митного союзу; для співробітників підприємств індустріального парку встановлена фіксована ставка індивідуального прибуткового податку - 9,0 \%, (на 25,0 \% менше за загальнореспубліканську); резиденти парку, а також їх працівники з числа іноземних громадян, звільняються від сплати обов'язкових страхових внесків з фонду їх заробітної плати. На частину доходу працівників резидентів парку з числа громадян Республіки Білорусь, що перевищує одноразовий розмір середньомісячної заробітної плати в республіці, обов'язкові страхові внески не нараховуються; відрахування в повному обсязі податку на додану вартість, сплаченого при придбанні товарів (робіт, послуг, майнових прав), використаних для проектування, будівництва і оснащення будівель і споруд в парку; звільнення (протягом 5 років з року виникнення валового прибутку резидента парку) від податку на прибуток по дивідендах, нарахованих засновникам; дозвіл використання іноземної валюти, цінних паперів i (або) платіжних документів в іноземній валюті при проведенні розрахунків між резидентами індустріального парку та резидентами Республіки Білорусь з валютних операцій, спрямованих на проектування і будівництво об'єктів парку; звільнення від відшкодування втрат сільськогосподарського і (або) лісогосподарського виробництва, спричинених вилученням або тимчасовим зайняттям сільськогосподарських земель і земель лісового фонду в межах парку, а також від компенсаційних посадок і компенсаційних виплат вартості видаляються, пересаджуваних об'єктів рослинного світу, компенсаційних виплат за шкідливий вплив на об'єкти тваринного світу та (або) середу їхнього життя; інші преференції [6-7].

Новими перевагами умов ведення бізнесу в індустріальному парку є: система залучення інвестицій, коли можливість реалізації того чи іншого інвестиційного проекту регулюється органами управління парку в рамках чинного в країні законодавства; визначені урядом пріоритети галузевого розвитку, мають величезний економічний потенціал для країни не тільки в даний час, але і в перспективі; захист інвесторів не тільки на рівні національного законодавства, а й відповідно до спеціальних міжнародних договорів; більш преференційний податковий режим, ніж у країн-сусідів, що дозволяє використовувати можливості законодавства ЄAEC за умов зростаючої конкуренції за єдиний ринок Білорусі, Росії та Казахстану.

Розглянутий міжнародний досвід функціонування національних та транснаціональних індустріальних парків є перспективною формою залучення інвестицій в країну та розвитку технологій, особливо з точки зору коопераційних відносин. Це не лише безпрецедентні пільги і преференції, а й утворення окремого і незалежного органу державного управління, який здійснює комплексне адміністративне обслуговування за принципом «єдиного вікна».

На відміну від КНР в Україні у 2014 р. створено Реєстр індустріальних (промислових) парків, в якому зареєстровано 49 парків. Включення до Реєстру індустріальних парків відбувається за умови, що на час включення в його межах відсутній цілісний майновий комплекс, що дозволяє здійснювати виробництво продукціï.

Створення та розвиток індустріальних парків в Україні відбувається під впливом таких факторів, як: прояв гострого дефіциту інвестиційних ресурсів та деформованої структури промисловості України; залежність від імпорту сировини, кон'юнктури на зовнішньому ринку; одержання державою легітимної з точки зору правил СТО можливості частково «субсидувати» інвестиційну діяльність; орендування підготовлених виробничих площ на території індустріального парку з можливістю одержати в користування виробничі, офісні та складські площі протягом незначного періоду, ніж придбання землі з наступним самостійним здійсненням будівництва; надання пільг зі сплати імпортного мита за обладнання та матеріали, які не виробляються на території України; розподілення в межах населених пунктів житлових та виробничих територій, винесення промислових зон за межі міст; високий показник чисельності осіб пенсійного віку (40,0-50,0 \% місцевого населення), який сформувався за рахунок застосування пільгових умов виходу на пенсію спеціалістів гірничо- видобувної спеціалізації; низький рівень доходів та тенденції до зростання бідності населення; технологічна відсталість, фізичне та моральне зношення ос- 
новних виробничих фондів містоутворюючих підприємств; низький рівень прояву підприємницької активності та неефективна спеціалізація малого підприємництва; криза комунальної інфраструктури, незадовільний стан благоустрою міст та дорожнього господарства, загострення проблем екологічної безпеки; вузький профіль спеціалізації працездатного населення та низький рівень їхньої мобільності, що призводить до посилення територіальних диспропорцій на ринку праці.

Найбільшими серед діючих індустріальних парків України можна назвати КП «Індустріальний парк «Рогань» та «Індустріальний парк «Свєма». Разом $з$ тим відзначимо, що серед спроектованих в Україні парків більшість мають локальний характер, а їхня спеціалізація обмежується 3-4-ма видами економічної діяльності, з яких один напрямок безпосередньо пов'язаний 3 наявним в регіоні великим підприємством, діяльність якого сьогодні не $\epsilon$ ефективною. Кілька індустріальних парків, такі як «Свєма», «Славута», «Чексіл», характеризуються багатопрофільною спеціалізацією і мають велике значення не лише для розвитку економіки регіону, але і розвитку окремих галузей у цілому.

Перспективним серед зареєстрованих індустріальних парків в Україні $є$ індустріальний парк "Industrial Forpost" (м. Дніпро), облаштування якого відбувається за рахунок коштів 3 місцевого та державного бюджетів (по 10,0 \% від запланованого обсягу інвестицій). Однак слід зазначити, що даний індустріальний парк $\epsilon$ винятком з загальної тенденції розвитку таких форм в Україні.

Учасники індустріального парку будуть звільнені від сплати земельного податку та ПДВ. Створення таких умов сприятиме розміщенню на території індустріального парку виробництва електричних машин (виготовлення дронів, робототехніки та іншої продукції машинобудування для відстеження засобів наземного транспорту, АПК), електричного устаткування, обладнання (виготовлення акумуляторних батарей тривалого терміну діiі), інноваційного виробництва металургійної промисловості, виробництва різної мінеральної продукції, а також надання комп'ютерних послуг. На теритоpiï індустріального парку "Industrial Forpost" також передбачено створити бізнес- ін к уба тор та відкрити виставковий центр.

За оцінками ініціаторів створення індустріального парку "Industrial Forpost" планується залучити понад 147,5 млн. дол. США інвестицій, що сприятиме створенню близько 2500 робочих місць протягом 2020-2024 pp.
Аналізуючи особливості діяльності індустріальних парків в КНР та в Україні можна зробити висновки про те, що [7]:

- цілі їх створення в різних країнах визначаються пріоритетністю завдань, що стоять перед тією чи іншою державою / регіоном;

- створюючи індустріальний парк необхідно враховувати наступні підходи: «Від майданчика» (наявна земельна ділянка, на території якої необхідно розмістити промислове виробництво); «Від задачі» (обирається майданчик для розміщення спеціалізованого виробництва та розмістити на ньому індустріальний парк);

- характерними рисами формування і розвитку ІП є: розташування поблизу населеного пункту, наявність великих логістичних центрів, розробка єдиної концепції розвитку комплексу, надання сучасних комунікаційних послуг;

- залежно від виду послуг, що надаються резидентам парка, вирізняють такі типи індустріальних парків: Greenfield-парк (пропонує резиденту незабудовану ділянку землі (купівлю i/або оренду) під будівництво для виробництва, можливе надання послуг з будівництва за вимогою замовника - built to-suit); Brownfieldпарк (пропонує купівлю i/aбо оренду резидентам індустріального парку наявних готових виробничих, складських, адміністративних приміщень, будівель і споруд інфраструктури, реконструкцію i/або капітальний ремонт); Комплексний-парк (поєднує в собі ознаки двох попередніх індустріальних парків); Еко-індустріальний парк - «...спільнота виробничого бізнесу, яка діє на основі спільної власності...», де «...кожна бізнес- одиниця намагається покращити взаємодію екологічної, економічної та соціальної функцій через співпрацю у вирішенні екологічних та ресурсних питань» [8-9];

- індустріальний парк має чіткі галузеві пріоритети, пов'язані з історичним розвитком регіону, а також орієнтується на його інвестиційну привабливість;

- ініціаторами створення індустріальних парків є: державні органи з розвитку економіки, керуючі компанії, власники об'єктів промислової нерухомості та земельних ділянок промислового призначення, університети;

- в світовій практиці функціонують схеми створення індустріального парку: викуп у існуючого підприємства земельної ділянки та будівель, надання їх в оренду тому ж або новому підприємству в наявному вигляді чи після реконструкції, розвитку та розширення території для нових користувачів; придбання земельної ділянки та будівництво споруди для конкретного підприємства під гарантію довгострокової оренди, зокрема «будівництво під зобов’язан- 
ня»; проектування і будівництво індустріального парку, пошук орендарів або покупців для підготовлених ділянок та будівель;

- у більшості індустріальних парків діє окрема власна професійно підготовлена керуюча компанія, яка займається пошуком та залученням інвесторів;

- функціонують дві моделі державного сприяння створенню та розвитку індустріальних парків - азіатська (держава може надати землю під проект, запропонувати стимули для залучення робочої сили, а також сприяти залученню міжнародного фінансування для розвитку інфраструктури; удосконаленням та іншими питаннями щодо створення індустріального парку займаються приватні компанії) та американська (громадські агентства розвитку відповідальні за більшість індустріальних парків, що розміщують виробництво; проект створення індустріальних парків фінансується переважно за рахунок реалізації державних і міжнародних програм розвитку);

- вирізняють моделі управління індустріальними парками: функціонують за підтримки розвитку керуючої компанії (надання підприємствам території для розміщення виробництва, розвитку інфраструктури та інших послуг); розвиваються без керуючої компанії (підприємства, які розмістили виробництво на території індустріального парку надають необхідні послуги або ж залучаються для цього інші компанії); одне з працюючих підприємств на території індустріального парку виконує функції керуючої компанії. Зацікавленість викликає трирівнева модель управління Китайсько-білоруським індустріальним парком «GreatStone": міжурядова координаційна рада (координаційний орган), основна функція полягає в постановці стратегічних цілей та координаційної підтримки роботи парку, вирішенні питань, що вимагають участі урядів двох сторін; адміністрація індустріального парку (орган управління), функція - оперативне та якісне комплексне обслуговування інвесторів (отримання необхідних дозволів, погоджень та інших державних послуг) за принципом «єдине вікно»; компанія 3 розвитку індустріального парку, функція якої полягає в будівництві інфраструктури та інших об'єктів для розвитку бізнесу, пошуку інвесторів;

- статус індустріального парку може бути наданий певній території за наступних умов: земля належить чи орендується керуючою компанією, яка розробляє план розвитку відповідної території; присутня інженерна інфраструктура, а керуюча компанія сприяє резидентам в процесі підключення до комунікацій, забезпечує охорону території, пожежну безпеку тощо; керуюча компанія допомагає резидентам організувати власний бізнес, володіючи деякими повноваженнями щодо розміщення об'єктів в межах індустріального парку, виступаючи посередником між інвестором та регіональною адміністрацією; керуюча компанія надає інвесторам ділові послуги (секретарські, кур'єрські, логістичні, бухгалтерські, пошук персоналу та ін.);

- види державної підтримки розвитку індустріальних парків, табл. 1: співфінансування інвестиційних проектів (інвестор представляє проект будівництва підприємства на теритоpiї індустріального парку; держава частково бере зобов'язання по фінансуванню, зокрема надання податкових пільг, прямий трансфер, надання пільгового кредитування та інше); опосередковане зменшення витрат інвесторів, окрім обслуговування індустріального парку (держава забезпечує підготовку, проживання висококваліфікованих фахівців, безпеку промислових об'єктів, часткове соціальне страхування); спрощення дозвільних та ліцензійних процедур; надання податкових і митних преференцій;

- особливого значення щодо створення та розвитку індустріальних парків набуває питання застосування податкових інвестиційних стимулів (табл. 1), зокрема пільгові ставки з податку на прибуток; звільнення від ввізного мита на обладнання та устаткування, що ввозиться учасниками індустріального парку; звільнення від сплати податку на нерухомість; звільнення від податку на землю; звільнення від податку на оренду землі; звільнення від екологічних податків тощо.

Незважаючи на спільні та відмінні риси щодо створення, діяльності індустріальних парків, їх чисельність в КНР та в Україні постійно зростає. Це обумовлено такими чинниками, як:

- індустріальні парки сприяють підвищенню інвестиційної привабливості у вітчизняних та іноземних інвесторів, зокрема у виробництво високотехнологічної продукції;

- розвиток індустріальних парків дозволяє сконцентрувати промислове виробництво на обмежених площах за межами великих міст;

- індустріальні парки забезпечують зростання надходжень у місцеві бюджети, передусім, за рахунок створення додаткових робочих місць і збільшення середньої заробітної плати; 


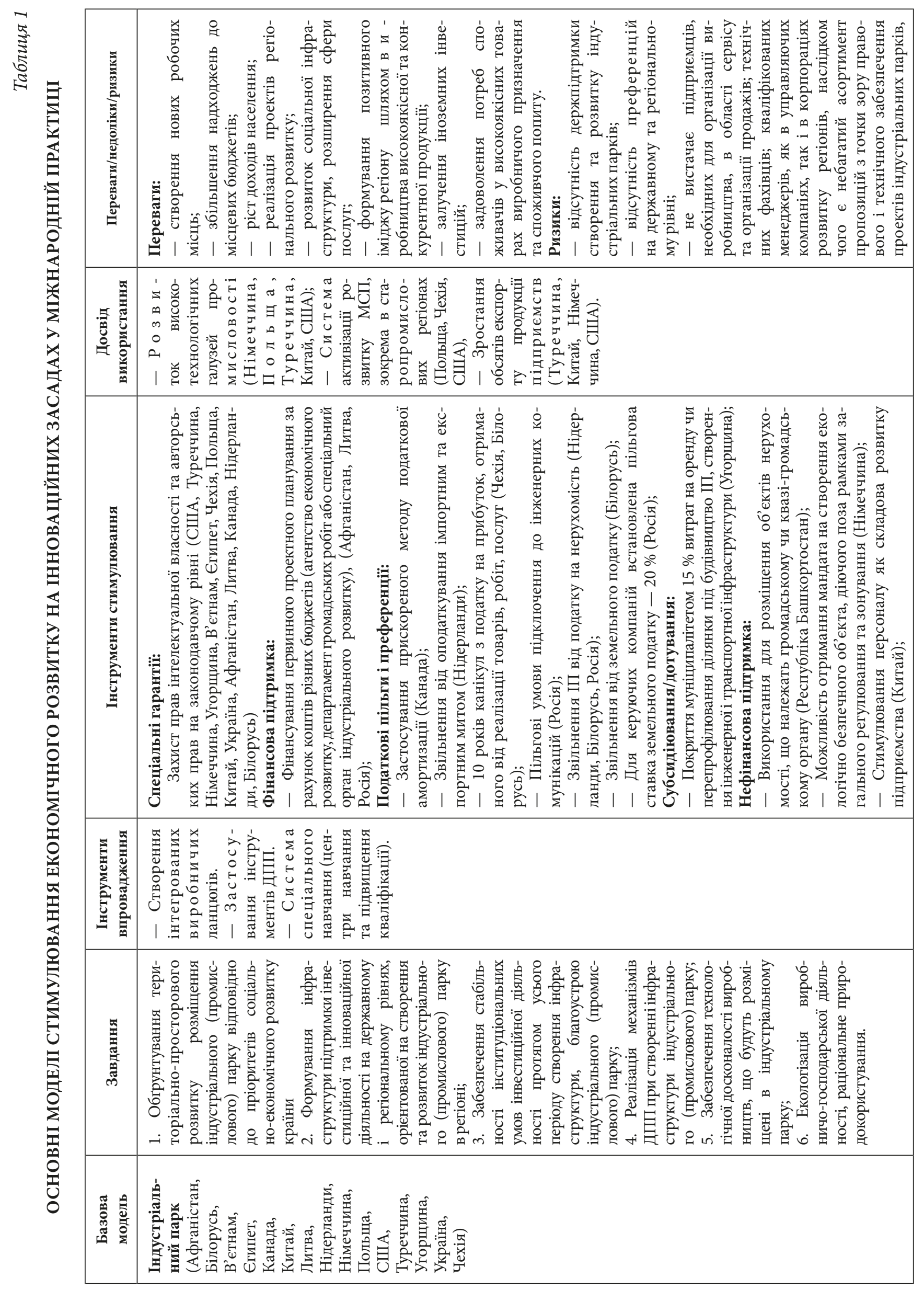




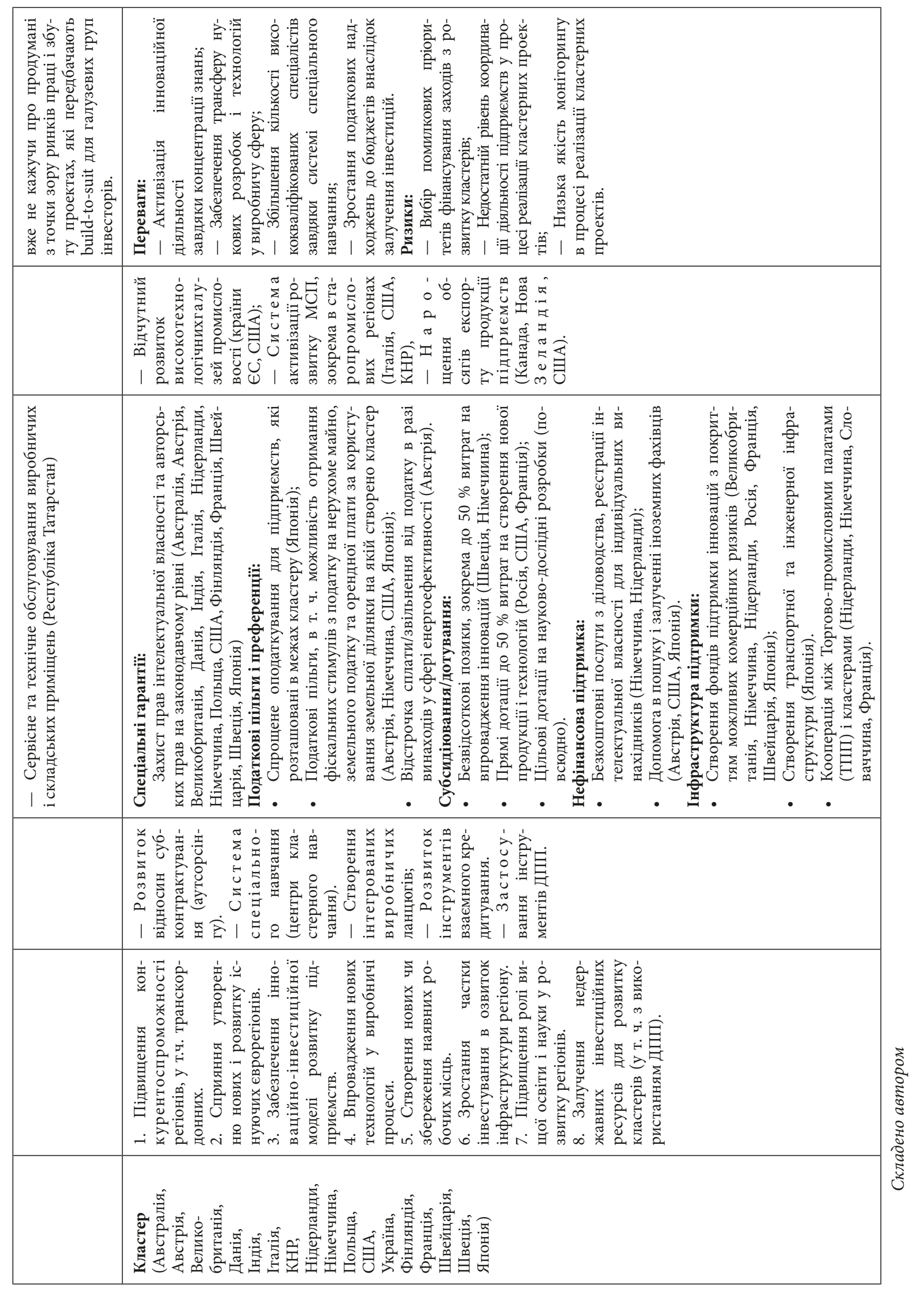


- підтримка в проведенні модернізації та реструктуризації підприємств усіх видів економічної діяльності задля підвищення їхньої рентабельності й конкурентоспроможності;

- створення умов для підвищення добробуту та купівельної спроможності населення регіону;
- держава отримує легітимну можливість «субсидувати» інвестиційну діяльність, зменшуючи реальні витрати бізнесу тощо.

В умовах розвитку сучасної економічної політики держави ії складовою частиною $€$ кластерна політика, яка розвивається за певними моделями: західноєвропейська, індійська, китайська, північноамериканська, скандинавська та японська (табл. 2).

Таблиия 2

\section{СВІТОВИЙ ДОСВІД МОДЕЛЕЙ ФОРМУВАННЯ ДЕРЖАВНОЇ КЛАСТЕРНОЇ ПОЛІТИКИ}

\begin{tabular}{|c|c|c|}
\hline $\begin{array}{c}\text { Назва моделі } \\
\text { державної кластерної } \\
\text { політики }\end{array}$ & $\begin{array}{c}\text { Характеристика особливостей моделей } \\
\text { державної кластерної політики }\end{array}$ & Країна-представник \\
\hline Західноєвропейська & $\begin{array}{l}\text { Ключова роль належить університетам і дослід- } \\
\text { ницьким інститутам, а також формування інно- } \\
\text { ваційної інфраструктури. В Італії на промислові } \\
\text { кластери припадає 43,0 \% чисельності зайнятих } \\
\text { в галузі, більше } 30 \text { \% обсягу національного екс- } \\
\text { порту. }\end{array}$ & $\begin{array}{l}\text { Великобританія (формування } \\
\text { кластерів відбувається на базі } \\
\text { традиційних галузей промисло- } \\
\text { вості- виробництво тканин, одягу } \\
\text { і меблів), Італія (кластери форму- } \\
\text { ються на територіях концентрації } \\
\text { малих підприємств розвитку тра- } \\
\text { диційних галузей обробної промис- } \\
\text { ловості, що відрізняються високим } \\
\text { рівнем спеціалізації при одночасній } \\
\text { експансії в суміжні галузі та регіо- } \\
\text { ни), Франція, Швейцарія. }\end{array}$ \\
\hline Індійська & $\begin{array}{l}\text { Фінансування кластерів відбувається за раху- } \\
\text { нок іноземних інвестицій. } 3 \text { метою підвищен- } \\
\text { ня експортних можливостей кластера уряд } \\
\text { відбирає найбільш пріоритетні (виробництво } \\
\text { тканин і трикотажу, а також харчова, верстато- } \\
\text { будівельна, фармацевтична галузі, програмне } \\
\text { забезпечення). Індійські кластери постачають } \\
\text { понад } 60 \text { \% експортної продукції країни. Слід } \\
\text { зазначити, що в } 14 \text { великих містах зосереджено } \\
80 \text { діючих кластерів, які обєєднують } 22559 \text { малих } \\
\text { промислових підприємств. }\end{array}$ & Індія. \\
\hline Китайська & $\begin{array}{l}\text { В основі формування кластерів лежить ініціати- } \\
\text { ва уряду і регіонів, шляхом створення особли- } \\
\text { вих зон розвитку високотехнологічних галузей, } \\
\text { серед яких автомобілебудування, електротех- } \\
\text { ніка, виробництво мобільних телефонів. Фінан- } \\
\text { сування кластерів здійснюється за допомогою } \\
\text { урядових грантів і венчурних фондів. Класте- } \\
\text { ри концентруються навколо іноземних заводів } \\
\text { з подальшою перспективою розвитку власних } \\
\text { виробничих потужностей. }\end{array}$ & Китай. \\
\hline $\begin{array}{l}\text { Північноамерикан- } \\
\text { ська }\end{array}$ & $\begin{array}{l}\text { Уряд реалізує функцію стимулювання кластер- } \\
\text { ної політики регіональних органів влади за до- } \\
\text { помогою надання грантів і, шляхом створення } \\
\text { агентств з розвитку кластерів. } \\
\text { У США понад } 60 \text { \% промислової продукції виро- } \\
\text { бляється економічними кластерами, діяльність } \\
\text { яких заснована на принципах партнерства і, } \\
\text { орієнтована на комерціалізацію ННТР, іннова- } \\
\text { ційну діяльність. }\end{array}$ & $\begin{array}{l}\text { Канада (біотехнологічний кластер } \\
\text { високих технологій та ін.), США } \\
\text { (комп'ютерний, автомобільний, } \\
\text { кластер індустрії, розваг і ін.). }\end{array}$ \\
\hline
\end{tabular}




\begin{tabular}{|c|c|c|}
\hline $\begin{array}{c}\text { Назва моделі } \\
\text { державної кластерної } \\
\text { політики }\end{array}$ & $\begin{array}{c}\text { Характеристика особливостей моделей } \\
\text { державної кластерної політики }\end{array}$ & Країна-представник \\
\hline Скандинавська & $\begin{array}{l}\text { Ініціатором створення кластерів є уряд, та- } \\
\text { кож як і розвиток дослідницької та технологіч- } \\
\text { ної кооперації, адресного інвестування коштів } \\
\text { в найбільш перспективні кластери, інтеграція } \\
\text { кластерів. Так, зокрема промислові кластери за- } \\
\text { безпечують } 10 \text { \% світового експорту продуктів } \\
\text { лісопереробки. }\end{array}$ & $\begin{array}{l}\text { Фінляндія (кластери формуються } \\
\text { на базі великих транснаціональних } \\
\text { компаній в лісовій, інформаційній } \\
\text { та телекомунікаційній галузях). }\end{array}$ \\
\hline Японська & $\begin{array}{l}\text { Кластери сформувалися на базі транснаціональ- } \\
\text { ної корпорації, яка практикує довгострокові } \\
\text { субконтрактні і субпідрядні відносини з групою } \\
\text { малих підприємств. Уряд і регіони проводять } \\
\text { політику, спрямовану на підтримку кластерів } \\
\text { і розвиток інноваційної інфраструктури. }\end{array}$ & $\begin{array}{l}\text { Японія (кластери в сфері інформа- } \\
\text { ційних технологій, біотехнологій, } \\
\text { електротехніки та автомобілебуду- } \\
\text { вання). }\end{array}$ \\
\hline
\end{tabular}

Складено автором

Проаналізувавши їх можемо зазначити, що існуючі моделі мають суттєві відмінності, виокремлені за масштабами, напрямками та формами державної підтримки: ціленаправлене фінансування створення та розвитку кластерів; пряма фінансова підтримка специфічних проектів; зниження податкового навантаження; інвестиції в створення та розвиток інфраструктури регіонів, освіта, тренінги і маркетинг; сприяння розвитку мережевої взаємодії між учасниками кластера, тощо.

Вирізняють особливості функціонування високотехнологічної і низькотехнологічної кластерної політики. Переваги високотехнологічної кластерної політики полягають у тому, що вона орієнтована на структурну перебудову економіки та укріплення конкурентоспроможності. Разом з тим існують певні недоліки, зокрема: більшість регіонів подібні за видами економічної діяльності, завдяки чому відбувається дублювання та надмірне вкладання інвестицій в аналогічні технології; відсутність передумов розвитку в регіоні (високий рівень поглинання нових технологій, необхідних ресурсів та ін.), а також зменшення чисельності робочих місць.

На відміну від високотехнологічної кластерної політики до переваг низкотехнологічної слід віднести: адаптованість кластерів до існуючого регіонального конкурентного середовища та створення значної кількості нових робочих місць чи збереження старих. Окрім переваг існують і недоліки, серед яких: руйнування процесу реструктуризації в результаті штучної підтримки застарілих виробництв; закріплення аутсайдерського статусу країни, тощо.
В залежності від ролі держави в процесі створення та розвитку кластера вирізняють декілька видів їх підтримки: повного циклу (держава реалізує довготривалий план розвитку території з урахуванням іiі галузевої спеціалізації; сприяє створенню сприятливих умов для компаній, які $є$ лідерами розвитку кластерів) та фрагментарної підтримки (надається підтримка створеному кластеру, діяльність якого корегується шляхом застосування інструментів економічної політики).

Кластерна політика КНР, як і інших країн світу базується на основі реалізації національної програми розвитку кластерів, у якій визначено два напрямки державної підтримки: ініціювання створення кластерів за рахунок значущого в масштабах країни проекту; підтримка існуючих кластерів і ініціатив «знизу в гору".

Кластерна політика на території КНР на відміну від України реалізується шляхом розроблення кластерної стратегії (визначено пріоритети в організації та розвитку кластерів) і кластерної програми (визначено заходи, терміни виконання, відповідальні виконавці та ін.), табл. 3. Кластерна стратегія є частиною національної інноваційної стратегії країни за якої значення уряду зводиться до фіксації загальних економічних правил, а реалізація конкретних кластерних ініціатив належить регіональній адміністрації та муніципалітетам.

Ще однією складовою кластерної політики слід вважати кооперацію між Торгово-промисловою палатою (ТПП) і кластерами. Як свідчить досвід КНР, ТПП $є$ активними партнерами, які входять до складу кластера або сприяють створенню сприятливого середовища для нього. 
Форми співробітництва можуть бути наступними [10-11]:

- ТПП є членом власних структур, приймають участь в діяльності кластера, надає частину послуг підприємствам;

- ТПП тимчасово обслуговує підприємства, які входять до кластера у різних сферах (інтелектуальні ресурси підприємства, інноваційна підтримка, інтернаціоналізація підприємств тощо);

- ТПП залучає своїх членів до кластера та пояснює процедуру створення і функціонування кластера.

Таблиия 3

\section{ДОСВІД РОЗРОБКИ СПЕЦІАЛЬНИХ ПРОГРАМ ФУНКЦІОНУВАННЯ КЛАСТЕРІВ В КНР ТА УКРАЇНІ}

\begin{tabular}{|c|c|}
\hline Країна & Програми, які сприяють розвитку кластерів \\
\hline Китай & $\begin{array}{l}\text { Кластерна політика формується муніципальною владою та одобрюється центральним } \\
\text { правлінням особливих зон розвитку високотехнологічних галузей. Центральне правлін- } \\
\text { ня відбирає фірми, яким надаються пільги (інформаційна сфера та біотехнології). Значна } \\
\text { увага надається розвитку власних інновацій, підвищенню технологічного рівня продукції } \\
\text { з метою скорочення розриву між конкурентоспроможністю економіки Китаю і розвинених } \\
\text { країн, в зв’язку з чим було створено урядом країни мережу офісів ліцензування технологій } \\
\text { в університетах. Така ситуація сприяє активізації кооперації бізнесу та академічної і вузівсь- } \\
\text { кої науки, сприяє комерціалізації результатів дослідницької } \\
\text { роботи, посиленню конкуренції. }\end{array}$ \\
\hline Україна & $\begin{array}{l}\text { Розроблено проекти нормативно-правових актів щодо формування основ державної політи- } \\
\text { ки в сфері кластеризації економіки України. Серед них: } \\
\text { - проект «Концепції створення кластерів в Україні» (2008 р.), в якому визначено перспек- } \\
\text { тиви впровадження кластерного підходу в економіці, виділено переваги кластерної орган- } \\
\text { зації виробництва для вітчизняної економіки, визначено концептуальні засади розвитку } \\
\text { кластерів; } \\
\text { - проект «Концепції загальнодержавної цільової програми розвитку промисловості Украї- } \\
\text { ни до } 2017 \text { року» (2008 р.), реалізація якого передбачала впровадження моделі кластерної } \\
\text { організації промисловості; } \\
\text { - проект «Національної стратегії формування та розвитку транскордонних кластерів» } \\
\text { (2009 р.), основна мета якого полягає у вирішенні проблем, повязаних з асиметрією розвит- } \\
\text { ку регіонів України, відтоком трудових, інтелектуальних та інших ресурсів з прикордон- } \\
\text { них регіонів країни, а також відставанням України від інших країн Європи за показниками } \\
\text { якості життя, рівня інвестиційної привабливості, конкурентоспроможності та розвиненості } \\
\text { інноваційного середовища. Подолання цих недоліків передбачається за рахунок запровад- } \\
\text { ження транскордонного співробітництва у сфері створення та } \\
\text { розвитку транскордонних кластерів. }\end{array}$ \\
\hline
\end{tabular}

Складено автором

На підставі проведеного аналізу ми можемо зробити наступні висновки: реалізація кластерної політики базується на організації взаємодії між органами державної влади та місцевого самоврядування, бізнесом, наукою, освітою; існує різноманітність форм і методів забезпечення кластерної політики, які відрізняються національними особливостями, концепцією кластерного підходу; застосування кластерного підходу можна розглядати в якості закономірного етапу розвитку економіки країни; кластерні політики, програми та проекти в кожній країні індивідуальні в процесі кластеризації; кластери стимулюють розвиток малого і середнього бізнесу; в рамках існуючого законодавства необ- хідно будувати відносини в форматі потрійної спіралі: наука - виконавча влада - бізнес.

Світовий досвід вказує на те, що в останні десятиліття процес формування кластерів відбувається активно, зокрема в КНР створено понад понад 150 од., а в Україні - 50 од. Вони формуються під впливом таких факторів, як: географія потенційного кластера (місце його розташування); сектор (на основі статистичних i документальних даних), вигодоодержувачі фінансової чи регіональної підтримки (підприємства, вищі навчальні наклади, науково-дослідні установи та ін.). Галузеві напрямки розвитку кластерів в КНР та Україні наведено в табл. 4. 
ГАЛУЗЕВИЙ РОЗВИТОК КЛАСТЕРІВ НА ТЕРИТОРІЇ КНР І УКРАЇНИ

\begin{tabular}{|c|c|}
\hline Галузеве ранжування розвитку кластерів & Місцерозташування кластеру \\
\hline \multicolumn{2}{|l|}{ КHP } \\
\hline Промисловий кластер інтегральних мікросхем «Чжанцзян» & м. Шанхай \\
\hline Промисловий кластер комп’ютерних програмних продуктів & м. Чєнду \\
\hline Промисловий кластер штампувального виробництва & м. Хуан’янь \\
\hline Промисловий кластер обладнання для рейкового транспорту & м. Чжучжоу \\
\hline Промисловий кластер напівпровідників і освітлювальних приладів & м. Янчжоу \\
\hline Промисловий кластер нових металів & м. Дан’ян \\
\hline Промисловий кластер взуттєвої промисловості & м. Цзіньцзян \\
\hline Промисловий кластер арматури для опалювальних систем & м. Тайчжоу \\
\hline Промисловий кластер інженерно-будівельної техніки & м. Чанша \\
\hline Промисловий кластер комплектного машино-технічного обладнання & м. Шєньян \\
\hline $\begin{array}{l}\text { Промисловий кластер суднобудівний (2 од.) } \\
\text { — компанія “STX Offshore \& Shipbuilding”" } \\
\text { — компанія "China Shipbuilding Industry Corporation" }\end{array}$ & м. Даляне \\
\hline \multicolumn{2}{|l|}{ Україна } \\
\hline Вінницький переробно-харчовий кластер & Вінницька область \\
\hline Лісовий і туристично-рекреаційний кластери & Волинська область \\
\hline Національний інноваційний кластер «Нові машини» & Дніпропетровська область \\
\hline Національний інноваційний кластер «Нові технології природокористування» & Донецька і Луганська області \\
\hline Лісовий і туристично-рекреаційний кластери & Житомирська область \\
\hline Транспортно-логістичний кластер & Закарпатська область \\
\hline $\begin{array}{l}\text { Інноваційний технологічний кластер «АгроБУМ», медовий кластер «Бджо- } \\
\text { ла не знає кордонів», харчовий кластер «Купуй Запорізьке. Обирай своє » }\end{array}$ & Запорізька область \\
\hline Кластер виробництва сувенірів «Сузір’я» & Івано-Франківська область \\
\hline $\begin{array}{l}\text { Національний інноваційний кластер «Енергетика сталого розвитку», } \\
\text { національний інноваційний кластер «Технології інноваційного суспільст- } \\
\text { ва», національний інноваційний кластер «Інноваційна культура суспіль- } \\
\text { ства», національний інноваційний кластер «Нові продукти харчування» }\end{array}$ & Київська область \\
\hline Львівський кластер IT та бізнес-послуг & Львівська область \\
\hline Кластер «Транзитний потенціал України» та ін. & Одеська область \\
\hline Регіональний кластер екологічно чистої продукції & Полтавська область \\
\hline Кластер деревообробки & Рівненська область \\
\hline $\begin{array}{l}\text { Регіональний кластер екологічно чистої продукції, Сумський будівельний } \\
\text { кластер }\end{array}$ & Сумська область \\
\hline Інноваційно-інвестиційний кластер & Тернопільська область \\
\hline $\begin{array}{l}\text { Харківський технопарк «Технополіс» - кластер альтернативної енергетики } \\
\text { і науково-освітній кластер }\end{array}$ & Харківська область \\
\hline Транспортно-логістичний кластер «Південні ворота України» & Херсонська область \\
\hline $\begin{array}{l}\text { Кластер сільського туризму, Хмельницький будівельний кластер, Хмельни- } \\
\text { цький швейний кластер, Кам'янець-Подільський туристичний кластер. }\end{array}$ & Хмельницька область \\
\hline
\end{tabular}

Складено автором на основі [12-17] 
Створення кластеру відбувається за одним з декількох існуючих сценаріїв: в Україні це переважно «знизу вгору» (окремі проекти і програми, інтегруючі потенційні учасники кластера); в КНР - «зверху вниз» (створення органів дорадчої діяльності та моніторингу, стратегії розвитку кластера); змішаний (поєднання особливостей двох шляхів «з низу вгору» $\mathrm{i}$ «зверху вниз»).

Згідно існуючої типології, в КНР та в Україні прийнято вирізняти кластери, що виникли в результаті еволюції процесу їх утворення:

- «неактивні» або «недовиконуючі» (виконання освітньої функції, можливості якої використовуються частково);

- «потенційні» (проявляють деякі ключові характеристики, спостерігається недостатність виробничих ресурсів, брак «критичної маси»);

- «працюючі» або «перевиконуючі» (самодостатні кластери, що випускають більше ніж сума продукції всіх компонентів цих кластерів, які працюють окремо).

На відміну від КНР в Україні Міністерством економіки України (2008 р.) було оприлюднено законопроект з легалізації кластерів, відповідно до якого пропонувалося виділити 4 типи кластерів: виробничі (об'єднання авто-, судо-, авіабудування); інноваційно-технологічні (географічно локалізовані компанії, пов'язані між собою виробництвом інноваційної продукції); туристичні; транспортно-логістичні.

В КНР та Україні існують й інші особливості поділу кластерів, в основу яких закладено особливості технологічних параметрів: індустріальні (займаються виробництвом традиційних товарів); інноваційні або інтелектуальні (мають значну частку інноваційної продукції кластера, а також сформовану інноваційну інфраструктуру).

Учасниками створення та функціонування таких типів кластерів є: підприємства (організації, фірми), які спеціалізуються на пріоритетних видах економічної діяльності; фірми-постачальники товарів/послуг для профільних підприємств; підприємства (організації, фірми), що займаються обслуговуванням галузей загального користування (інфраструктура: транспортна, енергетична, природоохоронна тощо); організації ринкової інфраструктури (консалтингові, аудиторські, страхові, кредитні тощо); некомерційні та громадські організації, об'єднання підприємців, торгово-промислові центри та агентства з розвитку підприємництва, регіонального та муніципального розвитку, залучення інвестицій, агентства з підтримки експорту товарів, державні та муніципальні фонди підтримки під- приємництва, фонди сприяння кредитуванню тощо.

Позитивний аспект створення та розвитку кластерів відіграє важливу роль у формуванні економічного середовища, оскільки в залежності від типів вони сприяють: оздоровленню економіки країни (комерційна концентрація, унікальність, стратегії та ін.); розвитку високотехнологічних галузей промисловості; активізації підприємницької діяльності, особливо в старопромислових регіонах; зростанню частки експорту виробленої продукції; створенню унікальних можливостей щодо підготовки висококваліфікованих спеціалістів поза межами галузевої підготовки (обмін досвідом, центри кластерного навчання та ін.).

У світовій практиці цікавим $є$ досвід КНР щодо підтримки створення та розвитку індустріальних парків. Зокрема, все розпочалося 3 розв'язання інфраструктурних проблем в країні, на вирішення яких було витрачено 80,0 \% з бюджету країни. Іноземні інвестиції надійшли до індустріальних парків після створення умов, необхідних для ведення бізнесу. Згодом була запропонована система управління індустріальними парками, яка характеризується наявністю таких особливостей: спеціальні податкові стимули для іноземних інвестицій; незалежність в здійсненні міжнародного співробітництва; економічні характеристики представлені у вигляді так званих «чотирьох принципів» (конструкція в першу чергу розрахована на залучення і використання іноземного капіталу; основними економічними формами $є$ китайсько-іноземні спільні підприємства і партнерства, а також повністю іноземні підприємства; виробництво в першу чергу експортно-орієнтованої продукції; економічна діяльність в першу чергу визначається ринком).

На сьогодні існує дієва система стимулів, що застосовується для функціонування індустріальних парків з метою залучення іноземних інвестицій. Зокрема, зменшення ставок митних зборів або відсутність таких; відсутність імпортних квот; лібералізація або відсутність валютного контролю; необмежена репатріація прибутку; зниження обмежень на іноземну власність; зниження бюрократичних бар'єрів; розвинута інфраструктура; спрощення адміністративних правил з відносною незалежністю місцевих планових органів; прямий доступ до планових структур провінційного і центрального рівня; поширення методу «податкові канікули».

Щодо підприємств-резидентів індустріального парку застосовується пільгова ставка по- 
датку на прибуток і 5-річні «податкові канікули» 3 повним або частковим звільненням від сплати даного податку (перші 2 роки - податок не стягується, наступні 3 роки - 50,0 \% від діючої ставки) [4-5; 7]. До 2008 р. пільгова ставка податку на прибуток становила 15 \% (на інших китайських підприємствах поза пільгових зон - 33,0 \%). Згідно з Постановою № 39 Держради КНР «Про перехідну політику надання пільг щодо податку на прибуток підприємств» від 26 грудня 2007 р., для підприємств-резидентів індустріальних парків 31 січня 2008 р. введений 5-річний перехідний період на нові ставки зазначеного податку: у 2008 р. - 18,0 \%, 2009 p. - 20,0 \%, 2010 p. - 22,0 \%, 2011 p. 24,0 \%, 2012 р. - 25,0 \% [18-20]. Дане правило поширюється тільки на резидентів, які були зареєстровані в індустріальному парку до 15 березня 2007 р. і раніше користувалися пільговою ставкою податку в розмірі 15,0 \%. Відносно «нових» резидентів індустріальних парків, зареєстрованих після 15 березня 2007 р., та 3 1 січня 2008 р. діє єдина для всіх підприємств КНР нова ставка податку на прибуток - 25,0 \%; податкова знижка до 0,0% на виробничі матеріали; самостійність при прийомі на роботу і звільнення працівників; підвищені нормативи на амортизаційні відрахування; узгоджені обмеження доступу на китайський внутрішній ринок для товарів, вироблених в зоні; надання посвідки на проживання, дозволу на роботу і податкових пільг для іноземців, що працюють в зоні.

Кожна форма організації інноваційної діяльності створена на основі відповідного акта Уряду КНР, а конкретні питання їх діяльності регулюються спеціальними правилами і положеннями, прийнятими на рівні місцевої влади з правами провінційного рівня.

Іноземний інвестор, який має намір інвестувати в ту чи іншу форму організації інноваційної діяльності, повинен дотримуватися положень «Каталогу галузей - керівництво для іноземних інвестицій» на предмет відповідності пропонованого ним проекту чинному в індустріальному парку законодавству. Відповідно до документу всі галузі і напрямки діяльності КНР розділені на чотири категорії: заохочувані для іноземних інвестицій, дозволені для іноземних інвестицій, обмежені для іноземних інвестицій і заборонені для іноземних інвестицій. Перелік включає три розділи, в яких перераховані заохочувані, що обмежуються і заборонені галузі. Слід зазначити, що «Каталог галузей керівництво для іноземних інвестицій» не застосовується в Шанхайській зоні вільної торгівлі, оскільки в їі межах діє окремий закритий перелік спеціальних обмежень для іноземних інвестицій.

На сайтах адміністрацій форм організації інноваційної діяльності опублікована детальна інформація про дозволені форми іноземної присутності в зонах, процедурах установи компаній $з$ іноземним капіталом, необхідних для реєстрації документів, режим оподаткування, митного, експортно-імпортного режимів тощо.

Що стосується законодавчої бази, орієнтованої на підтримку створення і функціонування індустріальних парків в Україні, то ії основу становлять Конституція України, Цивільний кодекс України, Господарський кодекс України, Земельний кодекс України, Податковий кодекс України, Митний кодекс України, Закон України «Про індустріальні парки», Закон України «Про регулювання містобудівної діяльності», Концепції індустріальних парків та рішення про їх створення, інші законодавчі акти України, а також міжнародні договори, згода на обов'язковість яких надана Верховною Радою України.

Відповідно до Концепції створення індустріальних (промислових) парків, схваленої розпорядженням Кабінету Міністрів України № 447-р. від 1 серпня 2006 р., було започатковано розвиток цього виду діяльності в нашій країні, визначено механізм та послідовність дій з реалізації державної політики у сфері створення та розвитку індустріальних (промислових) парків, гарантувалися широкі можливості для стимулювання інвестиційно-інноваційної діяльності в Україні.

Відповідно до Закону України «Про індустріальні парки» (2012р.), індустріальний парк $€$ «...визначеною ініціатором створення індустріального парку відповідно до містобудівної документації облаштованою відповідною інфраструктурою територією, у межах якої учасники індустріального парку можуть здійснювати господарську діяльність у сфері промислового виробництва, а також науково-дослідну діяльність, діяльність у сфері інформації та телекомунікацій на умовах, визначених цим Законом і договором про здійснення господарської діяльності у межах індустріального парку» [21].

3 метою подальшого розвитку індустріальних парків в Україні було прийнято у першому читанні за основу законодавчий пакет (№o 2554 а-д та 2555 а-д), який запроваджує податкові та митні інвестиційні стимули для нових вітчизняних промислових підприємств. 3 усього існуючого пакету стимулів, що успішно використовуються на світовій арені даний законодавчий пакет передбачає застосування лише 
деяких податкових преференцій, серед яких: звільнення на 5 років від податку на прибуток та на наступні 5 років половинна ставка (9,0 \%) за умови реінвестування цих коштів у розвиток виробництва; звільнення від ввізного мита на обладнання та устаткування для здійснення господарської діяльності в межах IП; розстрочка на 5 років імпортного ПДВ на обладнання та устаткування для здійснення господарської діяльності в межах IП; можливість отримання фіскальних стимулів з податку на нерухоме майно, земельного податку та орендної плати за користування земельною ділянкою державної чи комунальної форми власності, на якій створено індустріальний парк, за рішенням місцевої влади [5; 22-24].

Разом $з$ цим, проект законодавчого пакету (№№ 2554 а-д та 2555 а-д) містить чіткі норми прямої дії, які вимагають: здійснення профільної виробничої та науково-дослідницької діяльності; на території індустріального парку повинен діяти механізм офіційного працевлаштування $з$ чисельністю щонайменше 30 співробітників; середньомісячна заробітна плата повинна складати не менше 3-х мінімальних, тобто понад 11,1 тис. грн.

Зазначимо, що набуття таких законодавчих ініціатив, запровадження відповідного пакету стимулів стане першочерговим кроком на шляху до розбудови мережі діючих вітчизняних індустріальних парків. Як свідчить позитивний досвід КНР та інших країн світу, Україні необхідно докласти багато зусиль для створення рівних умов для інвесторів у зіставленні з країнами-конкурентами, де існує можливість залучати кредити під 2,0 \% річних, де вже існує мережа індустріальних парків та інших форм організації інноваційної діяльності з позитивними стимулами, преференціями, де новим інвесторам, роботодавцям надають бюджетні компенсації за створення робочих місць до 50,0 \% їх капітальних витрат, а також де промисловцям 3 30,0 \%-ю знижкою від ринкової вартості продають електрику та газ, де земля під промислове виробництво надається майже на безоплатній основі.

В регіонах України раніше діяли програми розвитку індустріальних парків, в яких визначено заходи державної підтримки організацій та підприємств, що здійснюють діяльність на їхній території, а також передбачено надання пільг для резидентів. Так, наприклад, затверджено «Державну цільову програму розвитку індустріального (промислового) парку «Свєма» в м. Шостці Сумської області на 2012-2015 роки» (постанова Кабінету Міністрів України № 1265 від 30 листопада 2011 р.), в якій зазначе- но заходи щодо створення умов розвитку цього індустріального парку (в частині розбудови сучасної виробничої і ринкової інфраструктури для забезпечення виробництва конкурентоспроможної, високотехнологічної продукції).

Ще одним прикладом може слугувати затверджена «Програма створення індустріальних парків на території Закарпатської області на 2008-2012 роки» (рішення Закарпатської обласної ради № 487 від 12 березня 2008 р.), метою якої є створення та визначення перспектив розвитку індустріальних парків на території регіону, зокрема започаткування пілотних проектів відносно створення індустріальних парків в районі м. Чоп та с. Соломонового (Ужгородський район Закарпатської області). Також розроблено концепції зі створення та функціонування на території регіонів України, серед яких: «Львівський індустріальний парк «Рясне-2», «Долина», «Славута», «Індустріальний парк «Центральний», «Індустріальний парк «Коростень», «Перший український індустріальний парк», «Соломоново», «Свєма» та ін. Дані програми завершені і не пролонговані. Індустріальні парки створюються і функціонують без підтримки держави.

Отже, активізація розвитку вітчизняної промисловості можлива через механізм індустріальних парків за умов реалізації пакету реформ, спрямованих на підвищення їх інвестиційної діяльності. 3 огляду на існуючі проблеми у вітчизняній практиці господарської діяльності, нагальними заходами сприяння створенню та розвитку мережі індустріальних парків Україні необхідно передбачити внесення доповнень до законодавчого пакету (№№ 2554 а-д та 2555 а-д) [5; 22-24]:

- реалізація масштабних інфраструктурних проектів в Україні;

- звільнення від сплати земельного податку земель промислового призначення на умовах спрямування «вивільнених коштів» на модернізацію та розвиток виробництва;

- безкоштовне приєднання до інженерних мереж для резидентів індустріального парку за рахунок інвестиційної складової тарифу;

- надання доступних довгострокових кредитів виробникам та підприємцям (створення Банку відбудови і розвитку з залученням міжнародних фінансових організацій для надання дешевих і «довгих» кредитів промисловим виробникам;

- надання державної фінансової підтримки галузям високотехнологічного виробництва та не сировинного експорту за рахунок 3,0\% промислово-сировинного збору з експорту необробленої промислової сировини; 
- надання фінансової підтримки не сировинного експорту (створення Експортно-кредитного агентства для страхування, гарантування експортних контрактів та часткової компенсації відсотків за експортними кредитами виробників);

- запровадження стимулів для реінвестування у промисловість та на науку - 200,0 \% амортизація необоротних активів виробничого та наукового призначення для підприємств індустріальних парків;

- надання переваги вітчизняній продукції при державних закупівлях (реалізація програми імпортозаміщення в публічному секторі економіки згідно із Законом України «Купуй українське, плати українцям!» тощо.

Реалізація означених напрямків, які сприятимуть створенню і розвитку мережі індустріальних парків на території України буде активізувати інвестиційну діяльність, сприяти збільшенню обсягів прямих інвестицій, стимулювати розвиток реального сектора економіки, сприяти створенню нових високотехнологічних виробництв і робочих місць, збільшення обсягів та асортименту випуску експортоорієнтованої продукції.

Розвиток стратегічного партнерства України і КНР відповідає довгостроковим інтересам двох країн і націлений на зміцнення їх міжнародних позицій, сприяння забезпеченню сталого розвитку та зростання конкурентоспроможності національних економік на основі поглиблення взаємовигідного співробітництва в різних сферах діяльності. 3 позиції загальних інтересів основними напрямками двостороннього співробітництва $€[11]$ :

- посилення взаємного ділового співробітництва в створенні транснаціональних кластерів в транспортно-логістичній та виробничій сферах;

- стимулювання створення високотехнологічних виробництв, в тому числі мережі транснаціональних індустріальних парків та кластерів;

- глибока і взаємна інтеграція українських і китайських виробників шляхом виробничої кооперації, реалізації інвестиційних проектів у напрямку створення спільних виробництв, зокрема транснаціональних індустріальних парків та кластерів;

- стимулювання залучення прямих китайських інвестицій в економіку України, розширення інших форм фінансового співробітництва, включаючи кредитні інструменти і надання технічної допомоги;

- забезпечення поліпшення умов доступу та розширення взаємних поставок товарів і послуг, спільне освоєння нових ніш на ринках третіх країн;

- формування спільних дослідницьких і науково-практичних центрів, спільний розвиток галузевої науки;

- подальше поглиблення прямого китайсько-українського міжрегіонального співробітництва в напрямку створення та розвитку транснаціональних виробничих кластерів та індустріальних парків тощо.

Як свідчить світовий досвід існують і успішно розвиваються транснаціональні індустріальні парки Європи, вагоме значення серед яких мають: сервісний центр "Eurode Deinstlustungszentrum” (Німеччина, Нідерланди); європейський Парк науки і бізнесу “AVAN-TIS” (Hiмеччина, Нідерланди); транснаціональний промисловий парк "Businesspark HeiligenkreuzSzentgotthard” (Угорщина, Австрія, Словенія); промисловий парк “Асcess” (Австрія, Чехія); транснаціональний індустріальний парк «Гмюнд-Чеське Веленіце» (Австрія, Чехія) та ін. [7; 26].

Аналізуючи дані щодо світового досвіду діяльності транскордонних індустріальних парків можна зазначити наступне: цілі створення ТІП у різних країнах визначаються пріоритетністю завдань, які стоять перед тією чи іншою державою або регіоном; характерними рисами у створенні та розвитку ТІП є: розташування поблизу населеного пункту; близькість до сировинних та матеріальних ресурсів; наявність розвиненої інфраструктури тощо; залежно від виду послуг, що надаються резидентам ТІП, вирізняють декілька типів ТIП: Greenfield-парк, Brownfield-парк; Комплексний парк; ТІП може бути створений державою, муніципалітетом чи приватною компанією; ТІП мають декілька моделей власності: державне володіння та управління ТІП; приватне володіння та управління ТІП; державно-приватне партнерство або спільні підприємства, які спільно створюються між державою та приватним сектором в межах ТIП; девелопер займається пошуком та залученням інвесторів із найбільших міжнародних та вітчизняних корпорацій, незалежних спеціалізованих компаній, тощо.

Сучасна ситуація у сфері створення та діяльності транснаціональних індустріальних парків в Україні характеризується низкою існуючих проблем, які потребують вирішення. Зокрема, це стосується таких питань, як: недосконалість договірно-правових відносин у частині регулювання питань використання земельних ділянок державної і комунальної власності, на яких можуть бути створені транснаціональні індустріальні парки (в частині 
використання виключно договорів оренди землі); відсутність чітко встановленого переліку видів діяльності, які доцільно впроваджувати в межах транснаціональних індустріальних парків; недосконалість норм чинного законодавства, зокрема в частині визначення оптимальних форм стимулювання залучення інвестицій, необхідних для облаштування транснаціональних індустріальних парків шляхом звільнення від сплати ввізного мита на устаткування, обладнання та комплектуючих до них матеріалів. Незважаючи на існуючі проблеми перші спроби відносно створення транснаціональних індустріальних (промислових) парків спостерігаються між Україною (Закарпатська область) та Угорською Республікою, концепція розвитку яких знайшла відображення у «Техніко-економічному обгрунтуванні щодо створення спільного українсько-угорського промислового парку”.

\section{ВИСНОВКИ ТА ПЕРСПЕКТИВИ ПОДАЛЬШИХ ДОСЛІДЖЕНЬ}

3 метою подальшого створення та розвитку транснаціональних індустріальних (промислових) парків в Україні необхідно здійснити заходи, які спроможні скоординувати роботу влади, науки, освіти та бізнесу. Зокрема це стосується питань [27-29]: удосконалення нормативно-правової бази 3 питань кооперації та функціонування транснаціональних індустріальних (промислових) парків; організації навчання представників основних груп (підготовка навчальної літератури та навчальних посібників з питань функціонування транскордонних індустріальних (промислових) парків; введення навчального курсу, модулів у вищих навчальних закладах, центрах підготовки і перепідготовки кадрів; формування груп менторів 3 питань створення та розвитку індустріальних (промислових) парків); створення на міжнародному та національному рівнях мережі організацій, які займаються питаннями функціонування транснаціональної кооперації, у тому числі у сфері розвитку транснаціональних індустріальних (промислових) парків; розробки методичних рекомендацій відносно створення та розвитку транснаціональних індустріальних (промислових) парків, зокрема 3 питань виявлення транскордонних ініціатив функціонування транснаціональних індустріальних (промислових) парків; механізмів підтримки та інструментів розвитку функціонування транснаціональних індустріальних (промислових) парків; ведення статистичної звітності з питань функціонування транснаціональних індустріальних (промислових) парків; розроблення пропозицій 3 питань організації торгівлі виготовленими товарами підприємствами транснаціональних індустріальних (промислових) парків; узагальнення та імплементації міжнародного досвіду з питань створення і розвитку транснаціональних індустріальних (промислових) парків; створення на національному та регіональному рівнях постійно діючого органу з питань впровадження транснаціональних індустріальних (промислових) парків; створення веб-сайту та загальнонаціональної бази даних 3 питань функціонування транснаціональних індустріальних (промислових) парків; розробка «Стратегії функціонування транснаціональних індустріальних (промислових) парків» та «Концепції спільного розвитку транснаціональних регіонів"; підготовки регіональної дорожньої карти у напрямку реалізації «Стратегії функціонування транснаціональних індустріальних (промислових) парків"; удосконалення механізму фінансування проектів транснаціональних кооперації у сфері створення i, розвитку транснаціональних індустріальних (промислових) парків, тощо.

Держава зацікавлена у створенні транснаціональних кластерів, оскільки реалізація кластерної політики має суттєві переваги, до яких слід віднести:

- здійснення структурної перебудови реального сектору економіки за рахунок розвитку наукоємних і високотехнологічних виробництв потребує посилення ролі держави, зокрема в частині ефективності реалізації всіх стадій інноваційного процесу (від ННТР до комерціалізації і виводу на ринок нової продукції);

- посилення інноваційної активності промислових підприємств за рахунок кооперації між науково-дослідним та виробничим сектором, розвитку державно приватного партнерства в інноваційній сфері, залученню висококваліфікованих кадрів, розвитку аутсорсингу та ін.;

- розвиток міжрегіональних зв'язків за рахунок державної підтримки створення та функціонування кластерів та усунення диспропорцій соціально-економічного розвитку регіонів.

Необхідно зазначити, що на відміну від індустріальних парків в Україні відсутнє інституційно-правове забезпечення щодо їх функціонування, тому до основних завдань кластерної політики в Україні слід віднести:

- створення та розвиток кластерів (розробка нормативно-правової бази щодо створення та функціонування кластерів, зокрема визначити на законодавчому рівні поняття 
«кластер», «кластерна політика», «кластеризація»; створення та реалізація державних програм сприяння розвитку кластерів; створення Реєстру кластерів в Україні);

- розвиток кластерних зв'язків та мережевого співробітництва (залучення вітчизняних та іноземних інвестицій в пріоритетні за видами економічної діяльності кластери; формування і просування кластерних ініціатив; розвиток людського капіталу; економічна освіта суб'єктів кластеру та спеціалістів навчальних закладів; фінансування спільних наукових досліджень; створення інформаційного поля для суб'єктів кластеру; розробка програм розвитку постачальників; розміщення державного замовлення на продукцію підприємств кластеру; контроль якості продукції і послуг, які постачаються виробниками кластеру в рамках програми державної закупівлі; програми розвитку конкурентного середовища; створення інфраструктурного забезпечення кластер них зв'язків; взаємодія місцевих органів влади з суб'єктами кластеру; трансфер технологій у кластері; формування співробітництва в середині кластера та ін.);

- збільшення впливу i відповідальності місцевих органів влади в умовах децентралізації стосовно забезпечення розвитку кластерів;

- реалізацію ефективної кластерної політики можлива в контексті комплексу заходів щодо суттєвого покращення інвестиційного клімату;

- розробку моделей використання механізму державно-приватного партнерства з метою залучення недержавних інвестиційних ресурсів для розвитку кластерів, перш за все забезпечення території необхідною інфраструктурою;

- законодавче визначення механізму створення транснаціональних кластерів. Зокрема укладання на рівні урядів країн-учасниць двосторонніх угод про створення транснаціональних кластерів, узгодження стратегій і планів розвитку національних частин транснаціональних кластерів. Досвід функціонування таких структур свідчить про їх позитивний вплив на соціально-економічний розвиток та міжнародне співробітництво країн-учасниць, стимулювання ділової активності, приплив інвестицій і вирішення проблем зайнятості.

До заходів державної підтримки процесу кластеризації в Україні необхідно віднести:

- ідентифікацію кластерів в економічному розвитку (моніторинг кластерів);

- підготовку представників державного сектору та ділового кола (проведення тренінгів і семінарів; розробка методичних матеріалів для держслужбовців, підприємців; навчання спеціалістів, які поширюватимуть ідеї щодо створення та розвитку кластерів);

- створення некомерційних організацій і комісій по кластерам з метою управління процесом кластеризації (асоціації, центри кластерного розвитку, некомерційні партнерства, агентство з проблем кластерної політики в Україні, комісії по кластерам при Комітеті ВРУ, Міністерстві екомічного розвитку і торгівлі України та ін.).

Серед заходів забезпечення розвитку кластерних ініціатив та співробітництва України з КНР пропонуємо наступне:

- надання організаційної підтримки кластерним ініціативам (зокрема, надання приміщень і обладнання для спільної діяльності учасників кластеру; кооперація підприємств кластера з суб'єктами інноваційної інфраструктури, закладами науки та освіти);

- комунікативне забезпечення співробітництва шляхом створення Реєстру кластерів в Україні та створення Internet-порталів ( $\mathrm{B}_{2} \mathrm{~B}$, $\left.\mathrm{B}_{2} \mathrm{~A}, \mathrm{~B}_{2} \mathrm{~A}\right)$;

- економічне стимулювання та надання фінансової підтримки співробітництва суб'єктів кластеру в інноваціях, маркетингу, освіті та науці (фінансування та створення кластерної інфраструктури на умовах державно-приватного партнерства (венчурні фонди, центри кластерного розвитку та ін.); конкурсне фінансування інвестиційних кластерних проектів та надання грантів на розробку нових технологій у кластері; надання пільг в процесі співробітництва у сфері інноваційної діяльності між державою, науково-дослідними установами і вищими навчальними закладами, та державних гарантій банкам під інвестиційні проекти суб'єктів кластера.

Окремим напрямком є роль ТПП України та регіональних ТПП, які здійснюють низку заходів щодо діяльності формування кластерної політики в країні, реалізацію конкретних кластерних ініціатив. Зокрема, це стосується вивчення, узагальнення та поширення світового досвіду у сфері кластеризації; проведення різноманітних заходів щодо популяризації сучасних методів організації виробництва, у тому числі на основі кластер них технологій; залучення до процесу кооперації підприємств МСБ. Але це $є$ недостатнім, тому пропонуємо: сприяти кооперації ТПП з регіональними ТПП, діловими асоціаціями, центральними та регіональними органами управління щодо вдосконалення нормативно-правового забезпечення; активізувати підготовку пропозицій та проектів законодавчих актів щодо розвитку 
промислового комплексу і підприємництва на основі кластерної моделі; сприяти укріпленню співробітництва влади, науки, бізнесу, виробництва та освіти; забезпечити через учбові центри ТПП впровадження системи інноваційних учбових програм щодо підготовки і пе- репідготовки спеціалістів, які беруть участь у функціонуванні галузевих кластерів; сприяти поширенню досвіду кластеризації на регіональному та національному рівнях; сприяти участі виробничих кластерів у відповідних міжнародних кластерних об'єднаннях.

\section{СПИСОК ВИКОРИСТАНИХ ДЖЕРЕЛ}

1. Бойко О.М. Індустріальні парки та розвиток інноваційної діяльності в Україні / Формування ринкових відносин в Україні. — № 4 (167). — 2015. - С. 66-71.

2. Єгоров I.Ю., Бойко О.М. Інституційно-правові засади щодо функціонування індустріальних та технологічних парків в Україні: ризики та перспективи. Міжнародна науково-практична конференція “The Productive Capacity of a Nation: Case of Ukraine” (29-30 червня 2017 р.). - К.: Київський національний університет ім. Т. Шевченка, 2017. - С. 123-127.

3. Бойко О.М. Розвиток інноваційного середовища України в європейському науково-технологічному просторі Економічний вісник університету: зб. наук. праць учених та аспірантів / ДВНЗ «ПереяславХмельницький державний педагогічний університет імені Григорія Сковороди». - ПереяславХмельницький: ДВНЗ «Переяслав-Хмельницький державний педагогічний університет імені Григорія Сковороди», 2017. - С. 243-251.

4. Бойко Е.Н. Экономический пояс шелкового пути: перспективы для Украины. Стратегия развития экономики Беларуси: вызовы, инструменты реализации и перспективы: сборник научных статей. В 4 ч. Ч. 2 / Национальная академия наук Беларуси, Институт экономики НАН Беларуси; редкол.: В. И. Бельский [и др.]. - Минск: Институт системных исследований в АПК НАН Беларуси, 2017. C. $81-88$.

5. Галасюк В.В. Індустіральні парки: світовий досвід та перспективи створення в Укораїні / Економічний аналіз. - Том. 28 № 1. - 2018. - С. 40-50.

6. Бойко Е.Н. Структурные составляющие инновационной среды национальной экономики: Украина и другие страны мира Материалы докладов международной научно-практической конференции «социально-экономическое развитие организаций и регионов Беларуси: эффективность и инновации», посвященной году науки. - Витебск: УО «ВГТУ”, 2017. - С.112-132.

7. Індустріальні парки в Україні: проблеми становлення та перспективи розвитку: монографія / Єгоров І.Ю., Бойко О.М., Грига В.Ю.; наук. ред. Єгоров І.Ю. - НАН України, ДУ «Інститут економіки та прогнозування НАН України”, Міністерство економічного розвитку і торгівлі України, Науково-дослідний економічний інститут. - К., 2015. - 140 с.

8. Porter M.E. Clusters and Competition. / Porter M.E. // On Competition. Cambridge: Harvard Business Review. - 1988. — Nov. Dec. — Vol. 76. — No.6. - P. 77.

9. Эффективность концентрации промышленных производств / Под ред. Л.В. Козловского, А.Д. Павловой. - Минск, 1970. - 145 с.

10. Кластерная политика [Электронный ресурс]. - Режим доступа: htpp: // www. ru.wikipedia.org/ wiki/\%

11. Бойко О.М. Міжнародний досвід становлення та розвитку транскордонних кластерів / Современные технологии науки и образования: европейские аспекты: Сборник материалов международной научно-практической конференции. Том 1 / Под ред. Савиной Г. Г. - Херсон - Познань: Издательство ЧП Вышемирский В. С., 2017. - С.10-15.

12. Эффективность концентрации промышленных производств / Под ред. Л.В. Козловского, А.Д. Павловой. - Минск, 1970. - 145 с.

13. Ленчук Е.Б., Власкин Г.А. Кластерный поход в стратеги инновационного развития зарубежных стран [Електронный ресурс]. - Доступен из: http:// www. institutiones.com

14. Клейнер Г.Б., Качалов Р.М., Нагрудная Н.Б. Синтез стратегии кластера на основе системно-интеграционной стратегии // Наука-Образование-Инновации. - 2008. № 7. - С.18-21.

15. Войнаренко М.П. Концепція кластерів - шлях до відродження виробництва на регіональному рівні / М.П. Войнаренко // Економіст. - 2000. — № 1. - С.29-33.

16. Развитие кластеров: сущность, актуальные подходы, зарубежный опыт / авт.-сост. С.Ф. Пятикин, Т.П. Быкова. - Минск: Тесей, 2008. - 72 с.

17. Романова Ю.А. Организационно-экономические основы развития кооперации на региональном уровне (теория, методология, практика): автореф. дис. ...д-ра экон. наук: 05.00 .05 / Романова Ю.А.Российский ун-т кооперации. - М., 2008. - 40 с. 
18. Гриценко C.I. Реалії та можливості становлення індустріальних парків у контексті забезпечення сталого розвитку України / Економіка і організація управління. - № 4. - 2016. C. 54-63.

19. Бойко О.М. Сучасні виклики транскордонної кооперації у напрямку функціонування транскордонних індустріальних парків в Україні / Фінансові механізми інноваційно-економічного розвитку України в умовах євроінтеграції [Текст]: матеріали II науково-практичної конференції, (м. Київ, 31 травня 2018 р.) / Київський університет імені Бориса Грінченка. - Київ, 2018. - С. 36-42.

20. Єгоров И.Ю., Бойко Е.Н. Формирование и развитие технопарков как инновационной формы ведения бизнеса / «Современные достижения науки и пути инновационного восхождения экономики региона, страны», Международная научно-практическая конференция (2017; Комрат). Международная научно-практическая конференция «Современные достижения науки и пути инновационного восхождения экономики региона, страны», (18 май 2017 года) / гл. ред.: Пармакли Дмитрий Михайлович ; орг. ком.: Раковчена Т. И. [и др.]. - Комрат: Комратский государственный университет, 2017 (Tipogr. «Centrografic»). - С. 360-365.

21. Закон України «Про індустріальні парки в Україні» [Електронний ресурс] / http://zakon.rada.gov.ua/ laws/show/5018-17

22. Бойко О.М. Світовий досвід функціонування індустріальних парків в країнах Европейського Союзу та можливості для України // Проблеми науки - 2016. - № 1(181) - С. 49-61.

23. Бойко О.М., Черненко С.М. Світовий досвід розвитку інноваційної сфери виробництва у країнах Європейського Союзу та Україні / Журнал Європейської економіки. - 2015. - Т. 14 (№ 3). C. 341-361.

24. Івашко О. Індустріальні парки в системі інвестиційної безпеки держави: теорія та практика / Економіка й управління національним господарством. - 2018. - № 4. С. 32-40.

25. Бойко O.М., Терон I.В. «Индустриальные парки в системе приоритетов инновационной трансформации рынка труда Украины в условиях евроинтеграции". / International Scientific-Practical Conference Modern Transformation of Economics and Management in the Era of Globalization: Conference Proceedings. (January 29, 2016) - Klaipeda: Baltija Publishing, 2016. — Pag. 69-74.

26. Бойко О.М. Транскордонна конвергенція індустріальних парків в рамках реалізації концепції «розумної спеціалізації» в Україні. / Розвиток співробітництва України із СОТ: матеріали міжнародного круглого столу / відп. ред. О.О. Борзенко; НАН України, ДУ «Ін-т екон. та прогнозув. НАН України». - Електрон. дані. - К., 2018. - С. 16-18.

27. Бойко Е.Н. Развитие инновационной среды национальной экономики Украины на основе реализации ресурсного потенциала индустриальных парков Проблемы прогнозирования и государственного регулирования соціально-экономического развития: материалы XVII Международнар. Науч. Конф. (Минск, 20-21 окт. 2016 г.) В 3 т. Т.3 / редкол.: А.В. Червяков [и др.]. - Минск: НИЭИ М-ва экономики Респ. Беларусь, 2016. - С.14-16.

28. Бойко О.М. Формування державної інноваційної політики на основі кластеризації Проблеми і перспективи інноваційного розвитку економіки: Матеріали XXI міжнародної науково-практичної конференції (Одеса, 12 - 15 вересня 2016 р. ) - Київ-Одеса: Національна академія наук України, ДУ «Інститут досліджень науково-технічного потенціалу та історії науки ім. Г.М.Доброва НАН України», 2016. - С. 27-32.

29. Кизим Н.И., Чередник В.И., Зайцева А.Ю. Кластерный поход к выбору приоритетных направлений устойчивого развития регионов / Проблеми економіки. - 2010. — № 3. - С. 44-55.

\author{
Бойко Елена Николаевна \\ кандидат экономических наук, старший научный сотрудник, \\ ведущий научный сотрудник, \\ ГУ «Институт экономики и прогнозирования НАН Украины» \\ 2. Киев, Украина

\title{
ОПЫТ УКРАИНЫ И КИТАЯ ПО СОЗДАНИЮ ОРГАНИЗАЦИОННЫХ ФОРМ ИННОВАЦИОННОЙ ДЕЯТЕЛЬНОСТИ
}

Аннотация. В статье рассмотрены инициативу развития индустриальных парков, в том числе в направлении трансрегионального сотрудничества между КНР и Сингапуром (индустриаль- 
ный парк «г.. Сучжоу - Сингапур», а также КНР и Белоруссией (индустриальный парк «GreatStone»). Осуществлен мониторинг развития индустриальных парков на территории Китая (индустриальный парк «Lianyungang Хinpu», индустриальный парк в Ханчжоу) и Украины (КП «Индустриальный парк» Рогань «,» Индустриальный парк «свему», а также индустриальных парках «Industrial Forpost», "Славута», «Чексил»). Определены тенденции функционируют ния индустриальных парков, а также общие и отличительные черты их развития в КНР и в Украине.

Перспективным направлением является создание украинского-китайских индустриальных парков, поэтому проанализированы особенности их создания и функционирования, приоритетные направления и риски.

Определены особенности кластерных инициатив, которые рассмотрены на примере Украины и КНР в аспекте отраслевого развития. Рассмотрены модели формирования государственной кластерной политики. Проанализированы особенности функционирования высокотехнологичной и низкотехнологической кластерной политики.

В теоретико-методологическом аспекте рассмотрены типологию действующих кластеров Осуществлен мониторинг функционирования кластеров на территории Украины и КНР. Onределены приоритетные направления их дальнейшего развития и риски.

Рассмотрен опыт разработки специальных программ функционирования кластеров в КНР и Украины.

Отдельное внимание уделено вопросу кооперации между Торгово-промышленной палатой (ТПП) и кластерами в КНР и в Украине.

Определены институционально-правовые основы функционирования организационных форм инновационной деятельности реального сектора экономики Украины и КНР, в частности на примере индустриальных парков (в том числе законодательный пакет №№ 2554 а-д и 2555 a-д), а также кластеров. Разработаны предложения по особенностей дальнейшего их создания, развития.

Ключевые слова: индустриальный парк; кластер; кластерная инициатива; транс региональное сотрудничество; индустриально-правовое обеспечение.

\section{Olena Boyko}

Ph.D. (Economics), Senior Research Fellow,

The State Organization "Institute of Economics and Forecasting

of the National Academy of Sciences of Ukraine"

ORCID ID: 0000-0002-6567-1679

e-mail:bhelena@ukr.net

\section{EXPERIENCE OF UKRAINE AND CHINA ON THE ESTABLISHMENT OF ORGANIZATIONAL FORMS OF INNOVATIVE ACTIVITY}

Abstract. The article examines the initiative for the development of industrial parks, in particular in the direction of trans-regional cooperation between China and Singapore (Suzhou-Singapore Industrial Park, as well as China and Great Britain (GreatStone Industrial Park). Monitoring of the development of industrial parks in China has been monitored (Industrial Park "Lianyungang Xinpu», Industrial Park in Hangzhou) and Ukraine («Industrial Park «Rogan»,» Industrial Park «Swema», as well as industrial parks «Industrial Forpost», "Slavuta», "Cheksil»). The trends of functioning of industrial parks are determined, as well as the common and distinctive features of their development in the PRC and in Ukraine.

A promising direction is the creation of Ukrainian-Chinese industrial parks, therefore the peculiarities of their creation and functioning, priority directions and risks are analyzed.

The features of cluster initiatives, which are considered on the example of Ukraine and the People's Republic of China in the aspect of branch development, are determined. Models of formation of state cluster policy are considered. The peculiarities of high-tech and low-tech cluster policy functioning are analyzed.

In the theoretical and methodological aspect the typology of operating clusters is considered. The monitoring of the functioning of clusters in the territory of Ukraine and the People's Republic of China has been monitored. The priority directions of their further development and risks are determined. 
The experience of working out of special programs of functioning of clusters in the People's Republic of China and Ukraine is considered.

Particular attention is paid to the issue of cooperation between the Chamber of Commerce and Industry (CCI) and clusters in the People's Republic of China and in Ukraine.

The institutional and legal foundations of the functioning of the organizational forms of innovation activity of the real economy sector of Ukraine and the PRC, in particular on the example of industrial parks (including the legislative package No. 2554 a-d and $2555 a$-d), as well as clusters, are determined. Proposals on the peculiarities of their further creation and development are developed.

Keywords: industrial park; cluster; cluster initiative; transregional cooperation; industrial and legal support.

\section{REFERENCES}

1. Boyko, O. M. (2015). Industrial parks and innovation development in Ukraine. Formation of Market Relations in Ukraine, 66-71. Retrieved January 11, 2019.

2. Yegorov, I. Y. (2018, December 25). The institutional and legal framework for the functioning of industrial and technological parks in Ukraine: Risks and perspectives. International Scientific and Practical Conference. The Productive Capacity of a Nation: Case of Ukraine, 123-127.

3. Boyko, O. M. (2017). Development of Innovative Environment of Ukraine in the European Scientific and Technological Space Economic. Bulletin of the University: Sb. Sciences Works of Scientists and Postgraduates, 243-251. Retrieved January 13, 2019.

4. Boyko, E. N. (2017). Economic Silk Road Belt: Prospects for Ukraine. Belarus Development. Strategy: Challenges, Implementation Tools and Prospects: A Collection of Scientific Articles, 81-88. Retrieved January 16, 2019.

5. National Academy of Sciences of Belarus, Institute of Economics, National Academy of Sciences of Belarus; Editorial: VI I. Belsky [and others]. - Minsk: Institute for System Research in the APC of the National Academy of Sciences of Belarus

6. Galasyuk, V. V. (2018). Industrial Parks: World Experience and Prospects for Creation in Ukoryain. Retrieved December 25, 2018, from https://www.econa.org.ua/index.php/econa/article/view/1465

7. Boyko, E. N. (2017). Structural components of the innovation environment of the national economy: Ukraine and other countries of the world. Socio-economic Development of Belarusian Organizations and Regions, 112-132. Retrieved January 16, 2019.

8. Yegorov, I. Y., Boyko, O. M., \& Gryga, V. Y. (2015). Industrial parks in Ukraine: Problems of formation and development prospects. Manuscript, NAS of Ukraine, Institute of Economics and Forecasting of NAS of Ukraine, Ministry of Economic Development and Trade of Ukraine, Research Institute of Economics, Kiev.

9. Porter M.E. (1988, November) Clusters and Competition. On Competition. Cambridge: Harvard Business Review, No.6, p. 77. Retrieved January 19, 2019.

10. Pavlova, A. D., \& Kozlovsky, L. V. (Eds.). (1970). The Efficiency of the Concentration of Industrial Production. Minsk, Belarus: Pavlova.

11. Cluster Policy. (n.d.). Retrieved January 22, 2019, from htpp: // www. ru.wikipedia.org/wiki/\%

12. Boyko, O. M. (2017). International experience of formation and development of cross-border clusters. Modern Technologies of Science and Education: European Aspects: Collection of Materials of the International Scientific-practical Conference, 1, 10-15. Retrieved January 23, 2019.

13. Pavlova, A. D., \& Kozlovsky, L. V. (Eds.). (2017). The Efficiency of the Concentration of Industrial Production. Minsk, Belarus.

14. Lenchuk, G. A, \& Vlaskin, E. B. (n.d.). Cluster voyage to strategies of innovative development of foreign countries. Retrieved January 16, 2019, from http:// www. institutiones.com

15. Kleiner, G. B., Kachalov, R. M., \& Nabrodnaya, N. B. (2008). Science-Education-Innovations, 7, 18-21. Retrieved January 14, 2019.

16. Voinarenko, M. P. (2000). The concept of clusters - the way to the revival of production at the regional level. Economist, 1, 29-33. Retrieved January 8, 2019.

17. Pyatkin, S. F., \& Bykov, T. P. (2008). Development of clusters: Essence, actual approaches, foreign experience. Minsk, Belarus: Theseus.

18. Romanova, Y. A. (2008). Organizational and economic bases for the development of cooperation at the regional level (theory, methodology, practice). Romanova Yu.A.Rossiysk un-t cooperation.

19. Gritsenko, S. I. (2016). Realia that can be installed in industrial parks near the context of the steel development of Ukraine. Economics and Organizational Management, 4, 54-63. Retrieved December 23, 2019. 
20. Egorov, I. Y., \& Boyko, E. N. (2017). Formation and development of technoparks as an innovative form of doing business. Modern Achievements of Science and Ways of Innovative Ascent of the Regional Economy, Countries, 360-365.

21. The Law of Ukraine «On Industrial Parks in Ukraine». (2012, June 21). Retrieved December 3, 2018, from http://zakon.rada.gov.ua/laws/show/5018-17

22. Boyko, O. M. (2016). World experience of functioning of industrial parks in the countries of the European Union and opportunities for Ukraine. Problems of Science, 1 (181), 341-361. Retrieved January 20, 2019.

23. Boyko, O. M., \& Chernenko, S. M. (2015). World experience of development of innovation production sphere in the countries of the European Union and Ukraine. Journal of the European Economy, 3, 341-361. Retrieved January 16, 2019.

24. Ivashko, O. (2018). Industrial parks in the system of investment security of the state: Theory and practice. Economics and Management of the National Economy, 4, 32-40. Retrieved January 18, 2019.

25. Boyko, O. M., \& Teron, I. V. (2016). Industrial Parks in the System of Priorities of the Innovative Transformation of the Ukrainian Labor Market in the Conditions of European Integration. Modern Transformation of Economics and Management in the Era of Globalization, 69-74. Retrieved January 15, 2019.

26. Boyko, O. M. (2018). Transboundary convergence of industrial parks within the framework of the implementation of the concept of «reasonable specialization» in Ukraine. Development of Ukraine's Cooperation with the WTO: Materials of the International round Table, 16-182. Retrieved January 26, 2019.

27. Boyko, E. N. (2016). Development of the innovative environment of the national economy of Ukraine on the basis of realization of the resource potential of industrial parks. Problems of Forecasting and State Regulation of Social and Economic Development, 14-16. Retrieved January 15, 2019.

28. Boyko, O. M. (2016). Formation of the state innovation policy on the basis of clusterization. Problems and Perspectives of Innovative Development of the Economy, 27-32. Retrieved January 19, 2019.

29. Kizim, N. I., Cherednik, V. I., \& Zaitseva, A. Y. (2010). Cluster approach to the selection of priority areas for sustainable development of the regions. Problems of Economics, 3, 44-55. Retrieved January 22, 2019. 